\title{
Genetic Engineering In BioButanol Production And Tolerance
}

\author{
Ashok Rao ${ }^{1}$; A. Sathiavelu ${ }^{1}$; S. Mythili ${ }^{{ }^{*}}$. \\ ${ }^{1}$ Vellore Institute of Technology - SBST Vellore, India.
}

\begin{abstract}
The growing need to address current energy and environmental problems has sparked an interest in developing improved biological methods to produce liquid fuels from renewable sources. Higher-chain alcohols possess chemical properties that are more similar to gasoline. Ethanol and butanol are two products which are used as biofuel. Butanol production was more concerned than ethanol because of its high octane number. Unfortunately, these alcohols are not produced efficiently in natural microorganisms, and thus economical production in industrial volumes remains a challenge. The synthetic biology, however, offers additional tools to engineer synthetic pathways in user-friendly hosts to help increase titers and productivity of bio-butanol. Knock out and over-expression of genes is the major approaches towards genetic manipulation and metabolic engineering of microbes. Yet there are TargeTron Technology, Antisense RNA and CRISPR technology has a vital role in genome manipulation of C.acetobutylicum. This review concentrates on the recent developments for efficient production of butanol and butanol tolerance by various genetically engineered microbes.
\end{abstract}

Key words: Butanol, CRISPR, biofuel, Clostridium acetobutylicum

*Authors for correspondence: smythili@ vit.ac.in 


\section{INTRODUCTION}

One of the greatest challenges for mankind in the 21 st century is to meet the growing demand for energy which is utilized in transportation, heating furnaces and other industrial processes in a suitable way ${ }^{1}$. Biofuel production is classified into four generation (based on raw material). First generation biofuel synthesized from edible plant material and second-generation biofuel derived from non-food vegetable like feed stocks (e.g. Lignocelluloses material). Third generation biofuel is derived from the oleaginous materials through heterotrophic mode (microbes like microalgae, yeast, bacteria). Fourth generation biofuel is based on direct use of $\mathrm{CO}_{2}$ through phototrophic mode 1,2 .

Ethanol is largely incorporated as biofuel in Brazil, USA and some European countries. Ethanol can be blended with petrol or used as neat alcohol in dedicated engines. Taking advantage of high octane number and heat of vaporization; it is an excellent fuel for future's advanced Flex-fuel hybrid vehicles ${ }^{2}$. In spite of all these qualities of ethanol, currently butanol, higher alcohols, alkanes, alkenes and biodiesel are preferred due to higher octane number and other physiochemical properties (as higher alcohol don't form azeotrope with water $)^{3-5}$. Traditionally, bioalcohols are produced by fermentation process from naturally occurring microbes like yeast Saccharomyces cerevisiae, bacteria like Zygomonas mobilis and Clostridium acetobutylicum ${ }^{6-8}$. According to Grand View Research Inc. there is a steep rise in demand for biobutanol production in the next few years due to efficient fermentation technologies and cellulosic extraction technologies. There is a growing interest in butanol production from chemical based synthesis to biobased ${ }^{9}$. According to literature there are 6,600 articles titled with butanol out of which 746 articles has title of butanol production and 55 articles shows enhanced butanol production by engineered microbe (i.e genetic/metabolic/other type of engineering). The comparative analysis of articles entitled with butanol production and tolerance are explained graphically in figure 1 .

The microbes producing butanol are of genus Clostridia, but are also reported in traces in various fungi (eg. Penicillium, Aspergillus species) and bacteria growing on the cereals ${ }^{10}$. The strain most commonly used in genetic engineering are Clostridium acetobutylicum and Clostridium beijerinckii. Other microbes which produce butanol are E.coli, Pseudomonas species and S.cerevisiae. The pathway followed by Clostridium species for acetone, butanol and ethanol production is depicted in figure 2. Table 1 shows a summary of all substrates utilized for biobutanol production, fermentation and purification process which was done in the year 2015. Table 2 depicts agricultural waste and industrial waste used for the production of butanol. There are various other microbes available for butanol production apart from Clostridium acetobutylicum. Lactobacillus and Pseudomonas were found to have butanol tolerance of $3 \%$ and $6 \%$ respectively ${ }^{11-14}$.

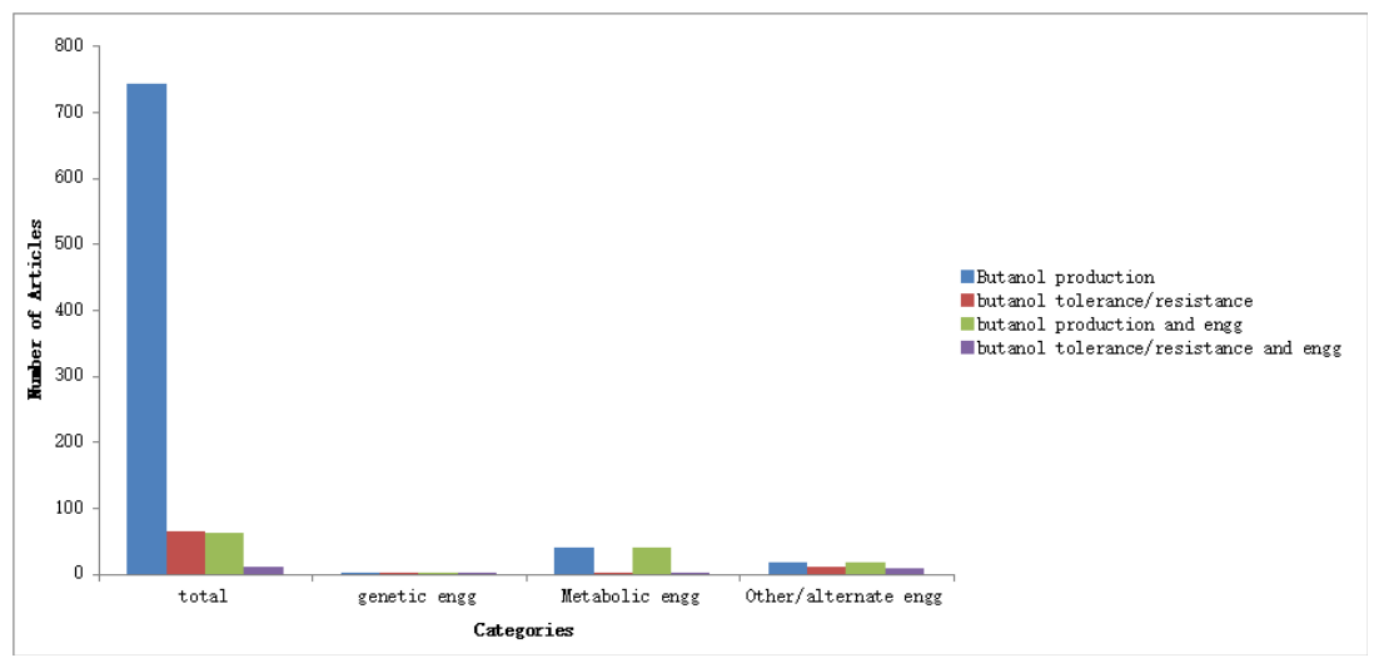

Figure 1. Graphical representation of butanol related (all key words in title) research article based on google scholar. (engg = engineering) 
Table 1:List of microbes showing butanol production from 2015 publications

\begin{tabular}{|l|l|l|l|l|l|}
\hline Microbe & Substrate & $\begin{array}{l}\text { Mode of } \\
\text { fermentation }\end{array}$ & Purification method & $\begin{array}{l}\text { Butanol } \\
\text { Yield }\end{array}$ & Ref. \\
\hline $\begin{array}{l}\text { S.cerevisiae } \\
\text { ASA2BR Adh1+5g }\end{array}$ & Glucose & Batch & - & $300 \mathrm{mg} / \mathrm{L}$ & 15 \\
\hline $\begin{array}{l}\text { C.tyrobutyricum } \\
\text { ack-adhE2 }\end{array}$ & Glucose & Fed batch & Gas stripping & $55 \mathrm{~g} / \mathrm{L}$ & 16 \\
\hline E.coli Bw2V & Glucose & Batch & - & $2.8 \mathrm{~g} / \mathrm{L}$ & 17 \\
\hline $\begin{array}{l}\text { C.acetobutylicum } \\
\text { ATCC } 824\end{array}$ & Glucose & continuous & Ex-situ recovery fermentation & $146.9 \mathrm{~g} / \mathrm{L}$ & 18 \\
\hline
\end{tabular}

Table 2: List of microbe using waste (agricultural/domestic/industrial) as substrate for butanol production

\begin{tabular}{|l|l|l|l|l|}
\hline Microbe & Waste used & Pretreatment & $\begin{array}{l}\text { Butanol Yield } \\
(\mathrm{g} / \mathrm{L})\end{array}$ & Ref. \\
\cline { 1 - 4 } $\begin{array}{l}\text { C.saccharoperbutylacetonicum } \\
\text { N1-4 }\end{array}$ & Palm oil waste & Enzymatic hydrolysis & 4.37 & 19 \\
\cline { 1 - 4 } C.acetobutylicum ATCC 824 & $\begin{array}{l}\text { Domestic organic } \\
\text { waste }\end{array}$ & Enzyme hydrolysis & 3 & 20 \\
\cline { 1 - 4 } C.acetobutylicum & $\begin{array}{l}\text { Industrial dairy } \\
\text { waste }\end{array}$ & Enzymatic hydrolysis & 7.5 & 21 \\
\cline { 1 - 4 } C.beijerinckii & Waste starch & - & 5.8 & 22 \\
\hline Immobilized C.acetobutylicum & &
\end{tabular}

GENETIC ENGINEERING IN BUTANOL PRODUCTION

\section{Clostridium acetobutylicum}

Clostridium acetobutylicum a spore producing anaerobic solventogenic microbe was first isolated by Weisman in the early 1900 . The fermentation carried out by the biofuel producer C.acetobutylicum is characterized by two phases, acidogenesis phase and solventogenesis phase. Acidogenesis occurs in exponential phase characterized by production of acid (acetate and butyrate). Solventogenesis occurs during transition of exponential and stationary phase characterized by production of solvents (acetone, butanol and ethanol) ${ }^{23}$. Amador-Noguez and his group reveal that in the kinetics of acetone, butanol and ethanol production there is a $\mathrm{pH}$ change in transition between acidogenesis and solventognesis. Metabolic remodeling reveals significant changes in an ordered series of metabolite concentration, involving all the metabolites synthesized during phase change from acidogenesis to solventogenesis ${ }^{24}$. Incorporation of induced gene with mathematical modeling of fermentation process provides a mechanical representation of $\mathrm{pH}$ induced switch between the two phases ${ }^{25}$.
Clostridium is metabolically engineered for butanol production. Various mutation strains are formed, the genetic accessibility problem has been resolved by the in vivo methylation protocol using host strains lacking the very active restriction endonuclease Cac824 ${ }^{26}$.

The strategies used for butanol production are disruption of butyrate, acetone, lactate and acetate pathways. The disruption of the butyrate acetone lactate pathway is done by 1) knockout/knockdown gene associated with butyrate, acetone, lactate and acetate 2) Inserting genes or over expressing genes (SpoA gene, groESL gene) associated with solvent production. Integrational plasmid technology, including replicating and non replicating plasmid is used, but due to low screening efficiency TargeTron technology is more preferred. Both technologies were used for improvement in butanol titer in solvent fermentation, but the disruption of $a d c$ gene causes increase in butanol production ratio from $70 \%$ to $80-85 \%$. However Antisense RNA Technology is a potent and flexible tool for microbial manipulation (silencing) of gene without changing the regulation of gene expression. It is used in silencing of the $c t f B$ gene for enhancing butanol ratio in solvent fermentation. The butanol production ratio was also improved when aad gene 
is inserted in the strain M5 which is lacking megaplasmid pSOL1 (containing aad gene and acetone producing gene). In fermentation process of butanol production by C.acetobutylicum using different lignocellulosic material by heterologous minicellulosome was confirmed in two studies (metabolic engineering of C.acetobutylicum using C.thermocellum and C.cellulolyticum). The deletion of CRE (catabolic responsive element) causes 7.5 fold increase in butanol production ${ }^{11,23-}$ 25. Deletion of the gene spoOA performed by CRISPR analysis in Clostidium beijerinckii also proved for ABE production. CRISPR analysis is a three year old method based on natural CRISPR (Cluster Regulatory Interspaced Short Palindromic Repeats) and CRISPR/Cas system (provide immune system by cleaving foreign DNA in bacteria and archea group). CRISPR analysis is a markerless and highly efficient deletion method of genome engineering done by simple cloning method. In this technique CRISPR array of target sequence transcribed and processed to form CRISPR-RNA (crRNA) guide Cas nuclease and cleave the target site with the help of protospaceradjacent motif (PAM). In type-II CRISPR analysis Cas9 is activated only with Trans Activating CRISPR RNA (TracrRNA) and CrRNA. It is a dual RNA complex guiding system. CRISPR technique has some limitations like the accuracy of CRISPR analysis depends on homologous recombinant efficiency of microbe, and the precise prediction of insertion site especially when target site is short ${ }^{27-29}$.
Escherichia coli

E. coli is engineered for various biotechnological applications. There are 62 articles found in google scolar with titled butanol and coli as key word out of which 22 articles related to butanol production . In last half decades, there are 13 articles (total 42 articles titled with coli butanol key words) showing butanol production from coli. Thus, it shows various advances in E.coli for biobutanol production ${ }^{6,30}$. The acetone-butanol-ethanol (ABE) fermentation pathway of C.acetobutylicum used in production of butanol was first constructed in E.coli to establish a baseline for comparison to other hosts 31,32 . Improved titers were seem to be achieved due to the co expression of S.cerevisiae formate dehydrogenase while over expression of E.coli glyceraldehyde3-phosphate dehydrogenase to elevate glycolytic flux improved titers to $580 \mathrm{mg} / \mathrm{L}$ and butanol production to $200 \mathrm{mg} / \mathrm{L}^{31,33}$. Currently the overall production of n-butanol and isobutanol is $0.001 \mathrm{~g} / \mathrm{L}$ to $30 \mathrm{~g} / \mathrm{L}$ and 4 to $50 \mathrm{~g} / \mathrm{L}$ respectively $6,17,31$. It was observed that the mutation of transcription factor of camp receptor protein causes increased tolerance of isobutanol up to $1.2 \% \quad(\mathrm{v} / \mathrm{v})$ against $2 \%$ isobutanol and productivity was $9.8 \mathrm{~g} / \mathrm{L}{ }^{34}$. However butanol production reached upto $2278 \pm 29 \mathrm{~g} /(\mathrm{L} * \mathrm{~d})$ due to stereo selectivity of butanone as proR over proS for production of R-2-butanol over S-2-butanol ${ }^{35}$. Recently E.coli was tested for potentials for the native promoter of hydrogenase I cluster Phya Bw2Vcarries plasmid pCNA-PHC and pENA-TA in anaerobic fermentation with extra glucose, the butanol production was up to $2.8 \mathrm{~g} / 1$ in batch culture bioreactor ${ }^{17}$. 


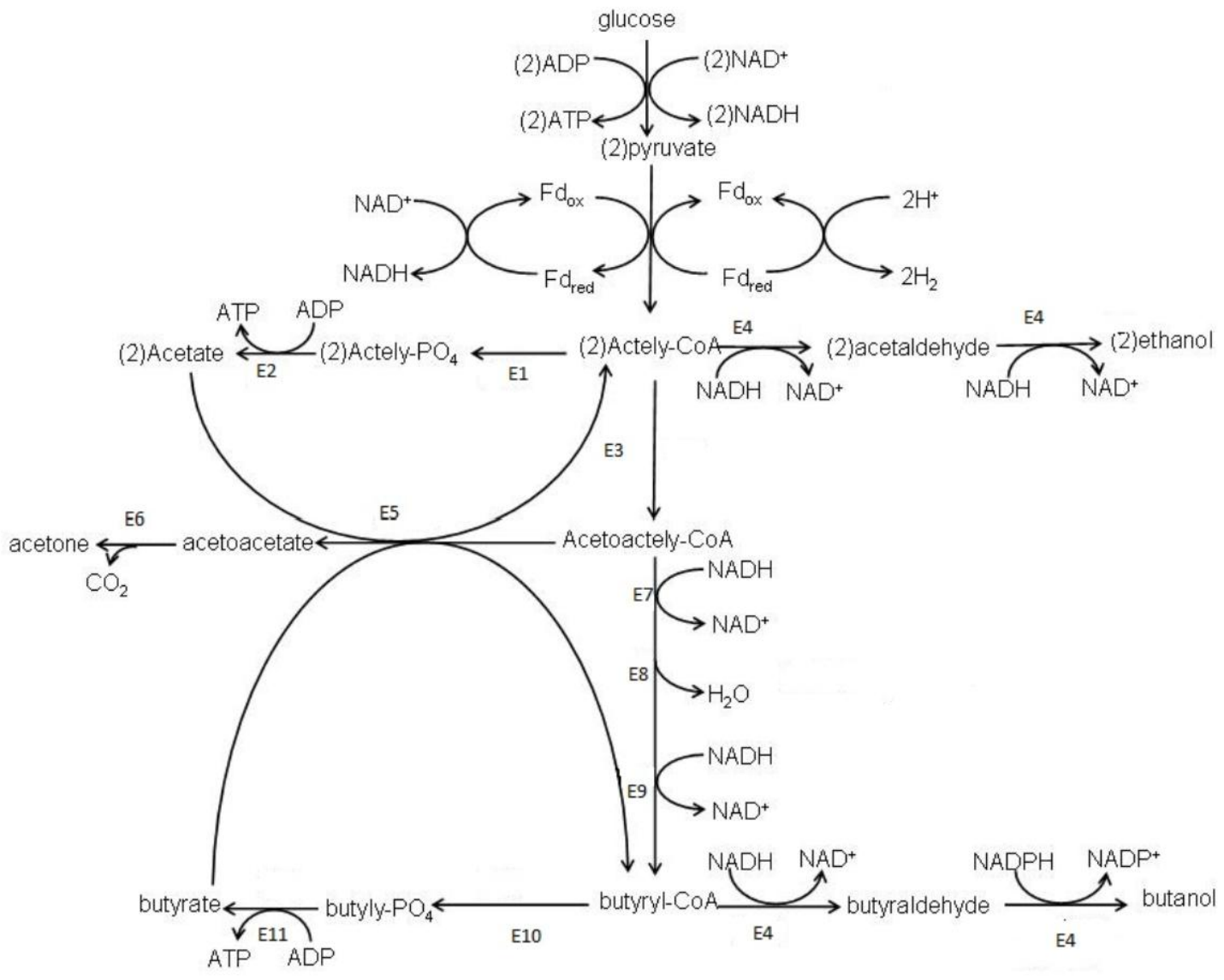

Figure 2. Pathway depicting butanol, acetone and ethanol production.E1 to E9 are enzymes involved in ABE pathway. E1-PTA-Phoshate acetyl transferase, E2-AK-Acetate kinase, E3-THL-ThiolaseA, E4-AAD-Alcohol aldehyde dehydrogenase, E5-CoAT- Co-A transferase, E6-AADC-Acetoacetate decarboxylase, E7-HBD-3 Hydroxybutryl CoA dehydrogenase, E8-CRO-Crontonase, E9-BCD-Butyryl-CoA dehydrogenase, E10-PTBPhosphate butryl-transferase, E11-BK-Butyrate Kinase ( modified 36)

\section{Cyanobacteria}

Carbon Dioxide as a sole source of carbon for all plants, which can also be used for chemicals as well as in biofuel production ${ }^{37}$. Synthetic pathway (Figure 3) was constructed in cyanobacteria Synechococcus elongates PCC7942 for the production of ethanol, n-butanol and 2,3-butandiol ${ }^{38-41}$. The n-butanol production was $14.5 \mathrm{mg} / \mathrm{L}$ in strain EL14 containing plasmid NSI T.d- ter (his tag) and plasmid NSII $a t o B, h b d$, crt and $a d h E 2$ whereas NADH driven metabolism (NADP dependent Adh from E.coli and Bldh from C.beijerinckii) in Synechococcus elongates EL22 shows $29.9 \mathrm{mg} / \mathrm{L}$. The low productivity was due to toxicity ${ }^{38-40}$. Butandiol was targeted because of the less toxicity and matches with the pathway of cyanobacteria. Production of butandiol was $2.38 \mathrm{~g} / \mathrm{L}$, which is significant in terms of exogenous pathway in cyanobacteria ${ }^{41}$.

\section{Thermoanaerobacterium saccharolyticum}

Thermoanaerobacterium saccharolyticum strain JW/SL-YS485 closely related to thermophilic anaerobe, a gram positive bacteria. Thermoanaerobacterium were well characterized and engineered for the production of biohydrogen, ethanol and butanol ${ }^{42,43}$. The gene cluster used were $h b d$, crt, bcd, eftA, eftB from Thermoanaerobacterium thermosaccharolyticum DSM571 and adhE2 from C.acetobutylicum. The pathway for butanol production from C.acetobutylicum which shows that from $10 \mathrm{~g} / \mathrm{L}$ of xylose produces $0.84 \mathrm{~g} / \mathrm{L}$ ( $21 \%$ of theoretical) however lactate deficient strains shows $1.05 \mathrm{~g} / \mathrm{L}$ $(26 \% \text { of theoretical })^{44}$. 


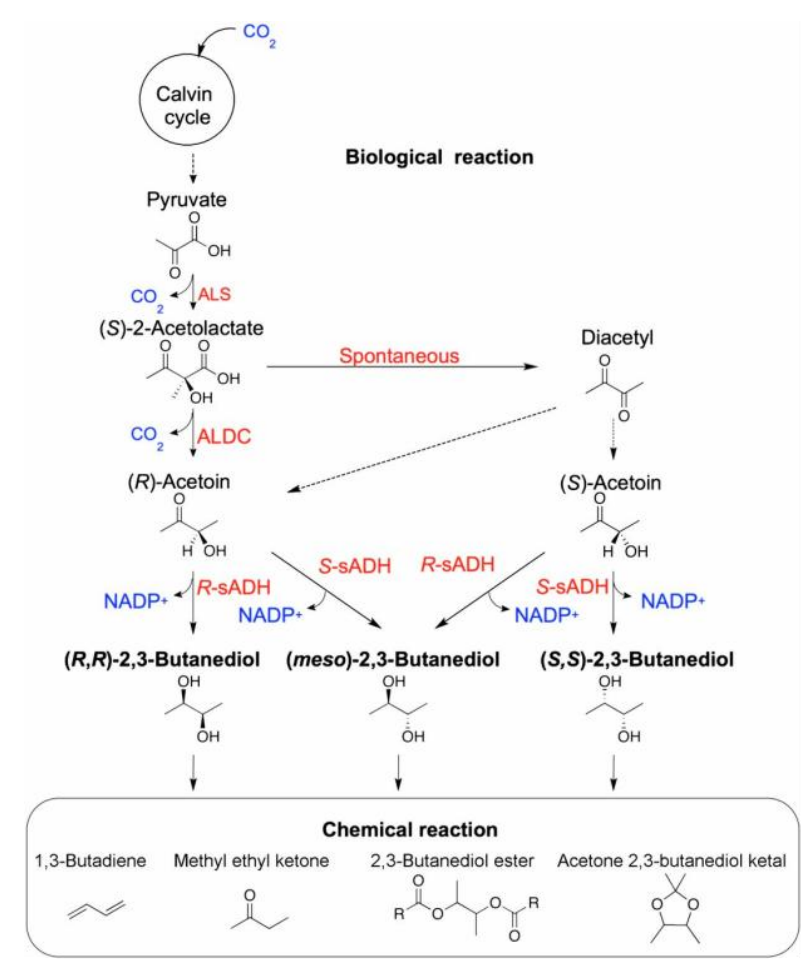

Figure 3:The pathway for acetoin and 2,3 butandiol production in S.elongates PCC7942. The acetoin/2,3butandiol production pathway contains three enzymatic steps from pyruvate 41 .

\section{Klebsiella pneumoniae}

Klebsiella a gram negative, rod shaped bacteria was genetically modified for 1-butanol, 2-butanol, butandiol, propanediol, ethanol and hydrogen ${ }^{45-47}$. Klebsiella pneumoniae was engineered to produce 2-butanol and 1-butanol from crude glycerol as a sole carbon source. 1-butanol production from the Klebsiella was done by modifying CoA-dependent pathway and 2-2-keto acid pathway was established by expressing the genes for ter-bdhB$b d h A$ and kivd respectively. The butanol titer and butanol production were found to be $15.03 \mathrm{mg} / \mathrm{L}$ and $27.79 \mathrm{mg}$ butanol/g-cell and $28.7 \mathrm{mg} / \mathrm{L}$ and $51.58 \mathrm{mg}$ butanol $/ \mathrm{g}$ cell. The native products are suppressed by antisense RNA strategy ${ }^{46}$. 1butanol was produced by engineering aketoisovalerate decarboxylase (kivd) and alcohol dehydrogenase $(a d h)$ from Lactococcus lactis into Klebsiella pneumoniae which bypassed the pathway for production of 2,3-butandiol. The yield was $320 \mathrm{mg} / \mathrm{L}$ which shows increment by 2 folds 48-50.

\section{Geobacillus thermoglucosidasius}

The Geobacillus is a facultative anaerobic, rodshaped, gram-positive and endospore-forming bacterium. Geobacillus species are capable to grows between $40^{\circ} \mathrm{C}$ and $70^{\circ} \mathrm{C}^{51}$. The Geobacillus was engineered for the production ethanol and isobutanol ${ }^{52,53}$. The Geobacillus thermoglucosidasius was engineered with acetohydroxy acid synthase gene and 2ketoisovalerate dehydrogenase gene from B.subtilis and L.lactis respectively and promoter region of lactate dehydrogenase gene from Geobacillus thermodenitrificans. The isobutanol produced was $3.3 \mathrm{~g} / \mathrm{L}$ from glucose as substrate. Lin et al., showed that isobutanol was produced at elevated temperature of $50^{\circ} \mathrm{C}^{53}$.

Pyrococcus furiosus

Pyrococcus furiosus is a heterophilic archaebacteria. It is cocci shaped, flagellated bacterium whose metabolic products are $\mathrm{CO}_{2}$ and $\mathrm{H}_{2}{ }^{54,55}$. The Pyrococcus furiosus was genetically engineered for butanol production at elevated temperature. Lactate dehydrogenase gene from Caldicellulosiruptor bescii was expressed in Pyrococcus for the production of 3hydroxypropionate (further used as electrofuel) using hydrogen as a substrate ${ }^{56-59}$. 1-butanol and 2-butanol production pathway was established in Pyrococcus furiosus. Genes responsible for the enzyme involved in first three reactions acetylCoA to crontylCoA isolated from Thermoanaerobacter tengcongensis and trans-2-enoyl-CoA reductase (ter) was from Spirochaete thermophila and butyraldehyde dehydrogenase $(\mathrm{Bad})$ and butanol dehydrogenase $(B d h)$ was obtained from Thermoanaerobacter sp. X514. The production of 1-butanol and 2 butanol was $70 \mathrm{mg} / \mathrm{L}$ and $15 \mathrm{mg} / \mathrm{L}$ after $48 \mathrm{hr}$ from genetically engineered Pyrococcus furiosus at $60^{\circ} \mathrm{C}$ respectively ${ }^{60}$.

Yeast

Saccharomyces is well known as yeast used in various fermentation processes, especially beverage industry and alcohol production ${ }^{61}$. Saccharomyces cerevisiae has been genetically modified, for the production of 1-butanol, isobutanol and 2-butanol. The optimal 1-butanol and isobutanol production was approximately matched with the theoretical production of butanol product. The maxima was $242.8 \mathrm{mg} / \mathrm{L}$ from glucose by deleting gene $\Delta a d h 1, \Delta i l v 2$ of YSG52 strain and $92 \mathrm{mg} / \mathrm{L}$ from glycine as a single protein source by using novel pathway by converting glycine into glyoxylate further $\beta$-ethylmalate then $\alpha$-ketovalerate into butanol by following Ehlich pathway ${ }^{62}$. The maxima for optimum production of isobutanol was $1620 \mathrm{mg} / \mathrm{L}$ in a YPH499 strain by using full cytoplasmic pathway with concomitant mitochondrial gene ILv2,ILV2, 


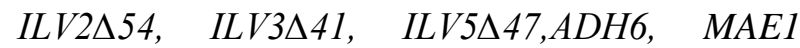

Lactococcus lactis gene kivD ${ }^{63}$.

Table 3: List of genetically engineered microbes to produce butanol

\begin{tabular}{|c|c|c|c|c|}
\hline Microorganism & Modification & Product & Yield & Ref. \\
\hline \multirow[t]{3}{*}{ E.coli } & $\begin{array}{l}\text { Deletion of adh, ldh, frd, fnr and pta } \\
\text { and insertion of bcd-etfAB from } \\
\text { C.acetobutylicum }\end{array}$ & \multirow[t]{3}{*}{ n-Butanol } & $0.37 \mathrm{~g} / \mathrm{L}$ & 31 \\
\hline & $\begin{array}{l}\text { GapA from E.coli over-expression } \\
\text { Fdh1 from } \quad \text { Saccharomycesis } \\
\text { cerevisiae adhE2, bcd, etfAB from C. } \\
\begin{array}{l}\text { acetobutylicum }\end{array}\end{array}$ & & $0.58 \mathrm{~g} / \mathrm{L}$ & 33 \\
\hline & $\begin{array}{l}\text { over-expression of kivd (L.lactis), } \\
A D H 2 \text { (S.cerevisiae), and the E.coli } \\
\text { ilvA, leuABCD, thrAfbrBC }\end{array}$ & & $1.250 \mathrm{~g} / \mathrm{L}$ & 79 \\
\hline S.cerevisiae & $\begin{array}{l}\text { ERG10 (E.coli) hbd, crt, adhE2 } \\
\text { (C.beijerinckii) ccr from S.collinus }\end{array}$ & n-Butanol & $2.5 \mathrm{mg} / \mathrm{L}$ & 80 \\
\hline \multirow[t]{6}{*}{ C.acetobutylicum } & Synthetic isopropanol operon & n-Butanol & $14.74 \mathrm{~g} / \mathrm{L}^{*}$ & 81 \\
\hline & $\begin{array}{l}\text { Knock out of Plasmid SOL1, and } a a d \\
\text { (ptb promoter) }\end{array}$ & & $11.396 \mathrm{~g} / \mathrm{L} \#$ & 82 \\
\hline & Ribosomal engineering & & $\begin{array}{l}12.48 \mathrm{~g} / \mathrm{L}(\text { butanol } \\
\text { tolerance of } 1.2 \\
\text { to } 1.4 \%)\end{array}$ & 83 \\
\hline & Coprodution of riboflavin & & $14.09 * \#$ & 84 \\
\hline & $A d c$ promoter insertion & & $8.9 \mathrm{~g} / \mathrm{L}$ & 85 \\
\hline & Integrated DNA tech approach & & $23.4 \mathrm{~g} / \mathrm{L}$ & 86 \\
\hline C.tyrobutyricum & Knock out of $a c k$ & n-Butanol & $16 \mathrm{~g} / \mathrm{L}$ & 87 \\
\hline S.elongatusEL14 & $\begin{array}{l}\text { Plasmid NSI T.d- } \operatorname{ter}(\mathrm{his} \text { tag) } \\
\text { Plasmid NSII atoB, hbd, crt and } \\
\text { adhE2 }\end{array}$ & n-butanol & $14.5 \mathrm{mg} / \mathrm{L}$ & 39 \\
\hline S.elongatusEL22 & $\begin{array}{l}\text { NADP dependent } A d h \text { from E.coli and } \\
\text { Bldh from C.beijerinckii }\end{array}$ & & $29.9 \mathrm{mg} / \mathrm{L}$ & 40 \\
\hline S.elongatus PCC7942 & Adh from C.beijerinckii & butandiol & $2.38 \mathrm{~g} / \mathrm{L}$ & 41 \\
\hline T.saccharolyticum & C.acetobutylicum & n-butanol & $1.05 \mathrm{~g} / \mathrm{L}$ & 44 \\
\hline \multirow[t]{2}{*}{ K.pneumoniae } & $\begin{array}{l}\text { Modifying CoA-dependent and 2-2- } \\
\text { ketoacid pathway Ter-bdhB-bdhA and } \\
\text { kivd }\end{array}$ & 1-butanol & \begin{tabular}{ll|}
$27.79 \mathrm{mg}$ & $1-$ \\
butanol/g cell & \\
$51.58 \mathrm{mg}$ & $2-$ \\
butanol $/ \mathrm{g}$ cell &
\end{tabular} & 50 \\
\hline & $\begin{array}{l}\alpha \text {-ketoisovalerate decarboxylase and } \\
\text { alcohol dehydrogenase from L.lactis }\end{array}$ & 2-butanol & $320 \mathrm{mg} / \mathrm{L}$ & 48 \\
\hline G.thermoglucosidasius & $\begin{array}{l}\text { Aceto-hydroxy-acid } r \text { sythase } \\
\text { (B.subtilis) and 2-keto-isovalerate } \\
\text { dehydrogenase (L.lacti) }\end{array}$ & Isobutanol & $3.3 \mathrm{~g} / \mathrm{L}$ & 53 \\
\hline
\end{tabular}




\begin{tabular}{|l|l|l|l|l|}
\hline P.furiosus & $\begin{array}{l}\text { Enzymes from acetylCoA to } \\
\text { crontylCoA (T.tengcogensis), ter }\end{array}$ & 2-butanol & $70 \mathrm{mg} / \mathrm{L}$ & $15 \mathrm{mg} / \mathrm{L}$ \\
& $\begin{array}{l}\text { (S.thermophila)Bad and Bdh } \\
\text { Thermoacetobacter sp.X514) }\end{array}$ & & 60 \\
\end{tabular}

Keys \# = calculated; * used for n-butanol however isopropanol operon is not produced that much amount at optimized condition; ldh (lactate dehydrogenase); pta (phosphate acetyltransferase), Kivd (2-ketoacid decarboxylase); ter (NADH dependent crotonyl-CoA specific trans-enoyl-CoA reductase); T.d-ter histidine tag (NADH dependent crotonyl-CoA especific to trans-enoyl-CoA reductase from Treponema denticola); ccr (ButyrylCoA dehydrogenase); ERG10 (acetoacetyl-CoA thiolase); fnr (DNA-binding transcriptional dual regulator, a global regulator for anaerobic growth), gapA (glyceraldehyde-3-phosphate dehydrogenase A); ack (acetate kinase); hbd (beta-hydroxybutyryl-CoA dehydrogenase); crt (crotonase); bcd (butyryl-CoA dehydrogenase); ptb (phosphor-transbutyrylase); $a d h$ (alcohol dehydrogenase); $b d h$ (butanol dehydrogenase); adhE2 (aldehyde-alcohol dehydrogenase); frd (fumarate reductase); atoB (acetyl-CoA acetyltransferase); Bad (butyraldehyde dehydrogenase); aad (alcohol aldehyde dehydrogenase); etfAB (electron transfer flavoprotein); bldh (butyraldehyde dehydrogenase); $f d h l$ $(\mathrm{NAD}(+)$-dependent formate dehydrogenase); ilvA; leuABCD (2-isopropylmalate synthase (LeuA), Isopropylmalate isomerase (consisting of two subunits LeuC and LeuD), metal-dependent 3-isopropylmalate dehydrogenase (LeuB)) ; thrAfbrBC ( thiolase Afeedback resistant with A and B thiolase)

\section{GENETIC ENGINEERING FOR BUTANOL TOLERANCE}

Solvent toxicity, is a one of the major limiting factors which hampers the cost-effective bioproduction of butanol and ethanol. Butanol as like other alcohol is toxic to cells in slightly higher concentrations. In Clostridium acetobutylicum, a functionally unknown protein encoded by SMB G1518 showing the alcohol interesting site was identified. Disruption of SMB G1518 and/or its down regulating gene SMB G1519 resulting increase in butanol tolerance, while decrements was observed when overexpressed. These genes also influence the production of pyruvate:ferredoxin oxidoreductase (PFOR) and flagellar protein hag, which maintain cell motility ${ }^{64}$. The mutants of C.acetobutylicum ATCC824 shows tolerance to $1.8 \%$ butanol ${ }^{65-67}$. Membrane composition shows similarity with a strain of Staphylococcus haemolyticus which has shown tolerance to increased solvent concentration ${ }^{6}$. However limited growth in butanol was found in
S.cerevisiae upto $2 \%$ but some microbe shows tolerance to $3 \%$ butanol while simulation results showed maximum tolerance of $4 \%$ by C.acetobutylicum 73,91,95,96,98,99. Shuttle vector pCAC1839 due gene have similarity with the xenobiotic responsive element and it shows an increase in tolerance of 13 to $81 \%$ on introduction to C.acetobutylicum ATCC $824^{6,68}$. The over expression of genes entC (isochorismate synthase) and $\mathrm{FeoA}$ (small iron tansport protein) shows an increase in butanol tolerance by $32.8 \%$ and $49.1 \%$ respectively, and by astE gene deletion butanol tolerance was enhanced by $48.7 \%$. By knock out of $\mathrm{Cac}-3319$ gene (histidine kinase production) by cis tron group II intron based inactivation system it enhances the biobutanol tolerance by $44.4 \%{ }^{69}$. Isobutyrlaldehyde (an intermediate metabolite) toxic to cyanobacteria due to its high concentration. Therefore isobutyrlaldehyde production was eluded by use of different pathway for the production of 2.3-butandiol ${ }^{70}$.

Table 4: List of microbes used for butanol tolerance

\begin{tabular}{|l|l|l|l|}
\hline Microorganism & Method & Tolerance & Ref. \\
\hline E.coli & Over-expressing rob & $2.1 \%$ & 88 \\
\cline { 2 - 5 } & Proton irradiation & $1.2 \%$ & 89 \\
\cline { 2 - 5 } & Protoplast fusion & $2 \%$ & 90 \\
\hline & $\begin{array}{l}\text { Deletion of astE over-expression of } \text { entC, } \\
\text { FeoA, factor cyclic AMP and } \text { OmpT }\end{array}$ & & 91 \\
\hline L.brevis & - & $3 \%$ & 73 \\
\hline C.beijerinckii & Antisense RNA down regulating gldA & $0.6 \%$ & 92 \\
\hline
\end{tabular}




\begin{tabular}{|l|l|l|l|}
\hline \multirow{4}{*}{\begin{tabular}{l} 
C.acetobutylicum \\
\cline { 2 - 4 }
\end{tabular}} & Over-expression of groESL & $0.75 \%$ & 93 \\
\cline { 2 - 4 } & Auxotrophic method & $1.6 \%$ & 67 \\
\cline { 2 - 4 } & Ribosomal mutation & $1.9 \%$ & 94 \\
\cline { 2 - 4 } & Nitrogen Ion beam implantation & $3 \%$ & 95 \\
\cline { 2 - 4 } & Artificial simulation of bioevolution & $4 \%$ & 96 \\
\hline S.cerevisiae & Mutation & $3.5 \%$ & 98 \\
\hline $\begin{array}{l}\text { Enterococcus } \\
\text { faecalis }\end{array}$ & Natural & $3 \%$ & 99 \\
\hline $\begin{array}{l}\text { Eubacterium } \\
\text { cylindroides }\end{array}$ & Natural & & \\
\hline Synechocystis & Over-expression of SigB & $2.5-3 \%$ & \\
\hline
\end{tabular}

Keys: $\operatorname{rob}$ (Right oriC binding); astE(Succinylglutamate desuccinylase); entC ( enterobactin C); FeoA(ferrous iron transport protein A); ompT( outer membrane protein); gldA(glycerol dehydrogenase); groESL( Heat shock proteins); $\operatorname{SigB}$ (RNA polymerase sigma B factor)

Integration of heterologous (HSPS) has been used to improve the tolerance of solvent in E.coli ${ }^{70,71}$. Overexpression of autonomous HSPs genes mainly GroES, GroEL, ClpB, GrpE and $L p l$ promoter increases E.coli tolerance to ethanol and biobutanol ${ }^{67,72-74}$. In addition to HSPS gene, mar-sol regulon genes which are responsible for solvent tolerance, mmsB, zwf a member of mar-sol was used for the ethanol tolerance. The researchers indicate that this regulon changes the membrane pumps for exportation of solvents ${ }^{75-77}$.

\section{CONCLUSION}

Butanol or isomer of butanol was not up to the mark for commercial use as biofuel. There are various microbes, including cyanobacteria, thermophilic bacteria, archeobacteria used for the production of butanol. The thermophilic bacteria is used as a key microbe for increasing the yield of butanol production and it also reduces the steps involved in downstream processing. Yet productivity was not satisfactory. Geobacillus thermodenitrificans and cyanobacteria are promising microbes for butanol yield and in case of eukaryotes isobutanol production of yeast was less than $1 \mathrm{~g} / \mathrm{L}$. Sterioselectivity also shows promising results. Heat shock proteins plays important role in enhancing cell tolerances towards solvent toxicity. In addition to it there is a regulon which increases the cell permeability towards butanol extraction by changing the membrane composition and increasing the number of solvent extraction pumps. Cyanobacteria and themophilic bacteria seem to be the best option in the future for the production of butanol as biofuel. The butanol tolerance and butanol ratio were most concerned factors for enhanced production of biobutanol in industrial scale.
CRISPR approach is a new technique and can be used as efficient technology for improving butanol tolerance, production and downstream processing. A wide range of thermophilic fungi and bacteria are identified which can be genetically manipulated for cost effective butanol production.

\section{ACKNOWLEDGMENT}

The authors acknowledge VIT University, Vellore. Tamil Nadu. and Dr.R. Natarajan, Director of CO2 and Green Technologies Centre,VIT University, Vellore, Tamil Nadu for support.

\section{REFERENCES}

1. Gray KA, Zhao L, Emptage M. Bioethanol. Current opinion in chemical biology. 2006 Apr 30;10(2):1416.

2. Hahn-Hägerdal B, Galbe M, Gorwa-Grauslund MF, Lidén G, Zacchi G. Bio-ethanol-the fuel of tomorrow from the residues of today. Trends in biotechnology. 2006 Dec 31;24(12):549-56.

3. Connor MR, Atsumi S. Synthetic biology guides biofuel production. BioMed Research International. 2010 Aug 12;2010. 
4. Wang B, Wang J, Zhang W, Meldrum DR. Application of synthetic biology in cyanobacteria and algae. Front Microbiol. 2012 Sep 19;3(344):344.

5. Zhang F, Rodriguez S, Keasling JD. Metabolic engineering of microbial pathways for advanced biofuels production. Current opinion in biotechnology. 2011 Dec 31;22(6):775-83.

6. Jin H, Chen L, Wang J, Zhang W. Engineering biofuel tolerance in non-native producing microorganisms. Biotechnology advances. 2014 Apr 30;32(2):541-8.

7. Lee SY, Park JH, Jang SH, Nielsen LK, Kim J, Jung KS. Fermentative butanol production by Clostridia. Biotechnology and bioengineering. 2008 Oct 1;101(2):209-28.

8. Lin Y, Tanaka S. Ethanol fermentation from biomass resources: current state and prospects. Applied microbiology and biotechnology. 2006 Feb 1;69(6):627-42.

9. Sherry James. Bio-butanol Market Size To Reach 17.78 Billion by 2022.Grand View Research Inc.2015-09-

23.http://www.marketwatch.com/story/bio-butanolmarket-size-to-reach-1778-billion-by-2022-grandview-research-inc-2015-09-23

10. Börjesson T, Stöllman U, Schnürer J. Volatile metabolites produced by six fungal species compared with other indicators of fungal growth on cereal grains. Applied and Environmental Microbiology. 1992 Aug 1;58(8):2599-605.

11. Ezeji T, Qureshi N, Blaschek HP. Butanol production from agricultural residues: impact of degradation products on Clostridium beijerinckii growth and butanol fermentation. Biotechnology and bioengineering. 2007 Aug 15;97(6):1460-9.

12. Liu S, Qureshi N. How microbes tolerate ethanol and butanol. New biotechnology. 2009 Oct 31;26(3):117-21.

13. Qureshi N, Saha BC, Cotta MA. Butanol production from wheat straw hydrolysate using Clostridium beijerinckii. Bioprocess and biosystems engineering. 2007 Nov 1;30(6):419-27.

14. Zheng J, Tashiro Y, Wang Q, Sonomoto K. Recent advances to improve fermentative butanol production: Genetic engineering and fermentation technology. Journal of bioscience and bioengineering. 2015 Jan 31;119(1):1-9.

15. Swidah R, Wang H, Reid PJ, Ahmed HZ, Pisanelli AM, Persaud KC, Grant CM, Ashe MP. Butanol production in $S$. cerevisiae via a synthetic $\mathrm{ABE}$ pathway is enhanced by specific metabolic engineering and butanol resistance. Biotechnology for biofuels. 2015 Jul 8;8(1):1.

16. Du Y, Jiang W, Yu M, Tang I, Yang ST. Metabolic process engineering of Clostridium tyrobutyricum $\triangle a c k-a d h E 2$ for enhanced n-butanol production from glucose: Effects of methyl viologen on NADH availability, flux distribution, and fermentation kinetics. Biotechnology and bioengineering. 2015 Apr 1;112(4):705-15.

17. Wang Q, Liu L, Shi J, Sun J, Xue Y. Engineering Escherichia coli for autoinducible production of nbutanol. Electronic Journal of Biotechnology. 2015 Mar;18(2):138-42.

18. Lee SH, Eom MH, Kim S, Kwon MA, Kim J, Shin YA, Kim KH. Ex situ product recovery and strain engineering of Clostridium acetobutylicum for enhanced production of butanol. Process Biochemistry. 2015 Nov 30;50(11):1683-91.

19. Tiam mun L, Ishizaki A, Yoshino S, Furukawa K. Production of acetone, butanol and ethanol from palm oil waste by Clostridium saccharoperbutylacetonicum N1-4. Biotechnology letters. 1995 Jun 1;17(6):64954.

20. López-Contreras AM, Claassen PA, Mooibroek H, De Vos WM. Utilisation of saccharides in extruded domestic organic waste by Clostridium acetobutylicum ATCC 824 for production of acetone, butanol and ethanol. Applied microbiology and biotechnology. 2000 Aug 1;54(2):162-7.

21. Ujor V, Bharathidasan AK, Cornish K, Ezeji TC. Evaluation of industrial dairy waste (milk dust powder) for acetone-butanol-ethanol production by solventogenic Clostridium species. SpringerPlus. 2014 Jul 28;3(1):387.

22. Kheyrandish M, Asadollahi MA, Jeihanipour A, Doostmohammadi M, Rismani-Yazdi H, Karimi K. Direct production of acetone-butanol-ethanol from waste starch by free and immobilized Clostridium acetobutylicum. Fuel. 2015 Feb 15;142:129-33.

23. Amador-Noguez D, Brasg IA, Feng XJ, Roquet N, Rabinowitz JD. Metabolome remodeling during the acidogenic-solventogenic transition in Clostridium acetobutylicum. Applied and environmental microbiology. 2011 Nov 15;77(22):7984-97.

24. Haus S, Jabbari S, Millat T, Janssen H, Fischer RJ, Bahl H, King JR, Wolkenhauer O. A systems biology approach to investigate the effect of $\mathrm{pH}$-induced gene regulation on solvent production by Clostridium acetobutylicum in continuous culture. BMC systems biology. 2011 Jan 19;5(1):1.

25. Lütke-Eversloh T, Bahl H. Metabolic engineering of Clostridium acetobutylicum: recent advances to improve butanol production. Current opinion in biotechnology. 2011 Oct 31;22(5):634-47.

26. Lütke-Eversloh T. Application of new metabolic engineering tools for Clostridium acetobutylicum. Applied microbiology and biotechnology. $2014 \mathrm{Jul}$ 1;98(13):5823-37.

27. Bruder M, Moo-Young M, Chung DA, Chou CP. Elimination of carbon catabolite repression in Clostridium acetobutylicum - a journey toward simultaneous use of xylose and glucose. Applied microbiology and biotechnology. 2015 Sep 1;99(18):7579-88. 
28. Copeland MF, Politz MC, Pfleger BF. Application of TALEs, CRISPR/Cas and sRNAs as trans-acting regulators in prokaryotes. Current opinion in biotechnology. 2014 Oct 31;29:46-54.

29. Wang Y, Zhang ZT, Seo SO, Choi K, Lu T, Jin YS, Blaschek HP. Markerless chromosomal gene deletion in Clostridium beijerinckii using CRISPR/Cas9 system. Journal of biotechnology. 2015 Apr 20;200:1 5.

30. Lan EI, Liao JC. Microbial synthesis of n-butanol, isobutanol, and other higher alcohols from diverse resources. Bioresource technology. 2013 May 31;135:339-49.

31. Atsumi S, Cann AF, Connor MR, Shen CR, Smith KM, Brynildsen MP, Chou KJ, Hanai T, Liao JC. Metabolic engineering of Escherichia coli for 1butanol production. Metabolic engineering. 2008 Nov 30;10(6):305-11.

32. Inui M, Suda M, Kimura S, Yasuda K, Suzuki H, Toda H, Yamamoto S, Okino S, Suzuki N, Yukawa H. Expression of Clostridium acetobutylicum butanol synthetic genes in Escherichia coli. Applied microbiology and biotechnology. 2008 Jan 1;77(6):1305-16.

33. Nielsen DR, Leonard E, Yoon SH, Tseng HC, Yuan C, Prather KL. Engineering alternative butanol production platforms in heterologous bacteria. Metabolic engineering. 2009 Sep 30;11(4):262-73.

34. Chong H, Geng H, Zhang H, Song H, Huang L, Jiang R. Enhancing E. coli isobutanol tolerance through engineering its global transcription factor cAMP receptor protein (CRP). Biotechnology and bioengineering. 2014 Apr 1;111(4):700-8.

35. Erdmann V, Mackfeld U, Rother D, Jakoblinnert A. Enantioselective, continuous (R)-and (S)-2-butanol synthesis: Achieving high space-time yields with recombinant E. coli cells in a micro-aqueous, solventfree reaction system. Journal of biotechnology. 2014 Dec 10;191:106-12.

36. Liu H, Wang G, Zhang J. The Promising FuelBiobutanol. INTECH Open Access Publisher; 2013.

37. Angermayr SA, Hellingwerf KJ, Lindblad P, de Mattos MJ. Energy biotechnology with cyanobacteria. Current opinion in biotechnology. 2009 Jun 30;20(3):257-63.

38. Deng MD, Coleman JR. Ethanol synthesis by genetic engineering in cyanobacteria. Applied and environmental microbiology. 1999 Feb 1;65(2):523-8.

39. Lan EI, Liao JC. Metabolic engineering of cyanobacteria for 1-butanol production from carbon dioxide. Metabolic engineering. 2011 Jul 31;13(4):353-63.

40. Lan EI, Liao JC. ATP drives direct photosynthetic production of 1-butanol in cyanobacteria. Proceedings of the National Academy of Sciences. 2012 Apr 17;109(16):6018-23.

41. Oliver JW, Machado IM, Yoneda H, Atsumi S. Cyanobacterial conversion of carbon dioxide to 2, 3- butanediol. Proceedings of the National Academy of Sciences. 2013 Jan 22;110(4):1249-54.

42. Sompong O, Prasertsan P, Karakashev D, Angelidaki I. Thermophilic fermentative hydrogen production by the newly isolated Thermoanaerobacterium thermosaccharolyticum PSU-2. International journal of hydrogen energy. 2008 Feb 29;33(4):1204-14.

43. Shaw AJ, Podkaminer KK, Desai SG, Bardsley JS, Rogers SR, Thorne PG, Hogsett DA, Lynd LR. Metabolic engineering of a thermophilic bacterium to produce ethanol at high yield. International Sugar Journal. 2009;111(1323):164-71.

44. Bhandiwad A, Shaw AJ, Guss A, Guseva A, Bahl $\mathrm{H}$, Lynd LR. Metabolic engineering of Thermoanaerobacterium saccharolyticum for nbutanol production. Metabolic engineering. 2014 Jan 31;21:17-25.

45. Biebl H, Zeng AP, Menzel K, Deckwer WD. Fermentation of glycerol to 1, 3-propanediol and 2, 3butanediol by Klebsiella pneumoniae. Applied microbiology and biotechnology. 1998 Jul 1;50(1):249.

46. Broglia M, Petrazzuolo F. Hydrogen production from Klebsiella oxytoca and medium induced metabolic switches. 2014

47. Ryan KJ, Ray CG. Medical microbiology. McGraw Hill.2004;(4):370

48. Oh BR, Heo SY, Lee SM, Hong WK, Park JM, Jung YR, Kim DH, Sohn JH, Seo JW, Kim CH. Erratum to: Production of isobutanol from crude glycerol by a genetically-engineered Klebsiella pneumoniae strain. Biotechnology letters. 2014 Feb 1;36(2):397-402.

49. Suzuki T, Seta K, Nishikawa C, Hara E, Shigeno T, Nakajima-Kambe T. Improved ethanol tolerance and ethanol production from glycerol in a streptomycinresistant Klebsiella variicola mutant obtained by ribosome engineering. Bioresource technology. 2015 Jan 31;176:156-62.

50. Wang M, Fan L, Tan T. 1-Butanol production from glycerol by engineered Klebsiella pneumoniae. RSC Advances. 2014;4(101):57791-8.

51. Nazina TN, Tourova TP, Poltaraus AB, Novikova $\mathrm{EV}$, Grigoryan AA, Ivanova AE, Lysenko AM, Petrunyaka VV, Osipov GA, Belyaev SS, Ivanov MV. Taxonomic study of aerobic thermophilic bacilli: descriptions of Geobacillus subterraneus gen. nov., sp. nov. and Geobacillus uzenensis sp. nov. from petroleum reservoirs and transfer of Bacillus stearothermophilus, Bacillus thermocatenulatus, Bacillus thermoleovorans, Bacillus kaustophilus, Bacillus thermodenitrificans to Geobacillus as the new combinations $G$. stearothermophilus, $G$. th. International Journal of Systematic and Evolutionary Microbiology. 2001 Mar 1;51(2):433-46.

52. Cripps RE, Eley K, Leak DJ, Rudd B, Taylor M, Todd M, Boakes S, Martin S, Atkinson T. Metabolic engineering of Geobacillus thermoglucosidasius for 
high yield ethanol production. Metabolic engineering. 2009 Nov 30;11(6):398-408.

53. Lin PP, Rabe KS, Takasumi JL, Kadisch M, Arnold $\mathrm{FH}$, Liao JC. Isobutanol production at elevated temperatures in thermophilic Geobacillus thermoglucosidasius. Metabolic engineering. $2014 \mathrm{Jul}$ 31;24:1-8.

54. Fiala G, Stetter KO. Pyrococcus furiosus sp. nov. represents a novel genus of marine heterotrophic archaebacteria growing optimally at $100 \mathrm{C}$. Archives of Microbiology. 1986 Jun 1;145(1):56-61.

55. Ma K, Zhou HZ, Adams MW. Hydrogen production from pyruvate by enzymes purified from the hyperthermophilic archaeon, Pyrococcus furiosus: a key role for NADPH. FEMS microbiology letters. 1994 Oct 1;122(3):245-50.

56. Berg IA, Kockelkorn D, Buckel W, Fuchs G. A 3 hydroxypropionate/4-hydroxybutyrate autotrophic carbon dioxide assimilation pathway in Archaea. Science. 2007 Dec 14;318(5857):1782-6.

57. Basen M, Sun J, Adams MW. Engineering a hyperthermophilic archaeon for temperaturedependent product formation. MBio. 2012 May 2;3(2):e00053-12.

58. Keller MW, Schut GJ, Lipscomb GL, Menon AL, Iwuchukwu IJ, Leuko TT, Thorgersen MP, Nixon WJ, Hawkins AS, Kelly RM, Adams MW. Exploiting microbial hyperthermophilicity to produce an industrial chemical, using hydrogen and carbon dioxide. Proceedings of the National Academy of Sciences. 2013 Apr 9;110(15):5840-5.

59. Thorgersen MP, Lipscomb GL, Schut GJ, Kelly RM, Adams MW. Deletion of acetyl-CoA synthetases I and II increases production of 3-hydroxypropionate by the metabolically-engineered hyperthermophile Pyrococcus furiosus. Metabolic engineering. 2014 Mar 31;22:83-8.

60. Keller MW, Lipscomb GL, Loder AJ, Schut GJ, Kelly RM, Adams MW. A hybrid synthetic pathway for butanol production by a hyperthermophilic microbe. Metabolic engineering. 2015 Jan 31;27:1016.

61. Albertin W, Marullo P, Aigle M, Dillmann C, de Vienne D, Bely M, Sicard D. Population size drives industrial Saccharomyces cerevisiae alcoholic fermentation and is under genetic control. Applied and environmental microbiology. 2011 Apr $15 ; 77(8): 2772-84$.

62. Lian J, Si T, Nair NU, Zhao H. Design and construction of acetyl-CoA overproducing Saccharomyces cerevisiae strains. Metabolic engineering. 2014 Jul 31;24:139-49.

63. Matsuda F, Ishii J, Kondo T, Ida K, Tezuka H, Kondo A. Increased isobutanol production in Saccharomyces cerevisiae by eliminating competing pathways and resolving cofactor imbalance. Microbial cell factories. 2013 Dec 5;12(1):1.
64. Jia K, Zhang Y, Li Y. Identification and characterization of two functionally unknown genes involved in butanol tolerance of Clostridium acetobutylicum. PloS one. 2012 Jun 29;7(6):e38815.

65. Baer SH, Blaschek HP, Smith TL. Effect of butanol challenge and temperature on lipid composition and membrane fluidity of butanol-tolerant Clostridium acetobutylicum. Applied and environmental microbiology. 1987 Dec 1;53(12):2854-61.

66. Lin YL, Blaschek HP. Butanol production by a butanol-tolerant strain of Clostridium acetobutylicum in extruded corn broth. Applied and Environmental Microbiology. 1983 Mar 1;45(3):966-73.

67. Soucaille P, Joliff G, Izard A, Goma G. Butanol tolerance and autobacteriocin production by Clostridium acetobutylicum. Current Microbiology. 1987 Sep 1;14(5):295-9.

68. Zingaro KA, Nicolaou SA, Yuan Y, Papoutsakis ET. Exploring the heterologous genomic space for building, stepwise, complex, multicomponent tolerance to toxic chemicals. ACS synthetic biology. 2014 Feb 19;3(7):476-86.

69. Xu M, Zhao J, Yu L, Tang IC, Xue C, Yang ST. Engineering Clostridium acetobutylicum with a histidine kinase knockout for enhanced n-butanol tolerance and production. Applied microbiology and biotechnology. 2015 Jan 1;99(2):1011-22.

70. Atsumi S, Higashide W, Liao JC. Direct photosynthetic recycling of carbon dioxide to isobutyraldehyde. Nature biotechnology. 2009 Dec 1;27(12):1177-80.

71. Kang HJ, Heo DH, Choi SW, Kim KN, Shim J, Kim $\mathrm{CW}$, Sung HC, Yun CW. Functional characterization of Hsp33 protein from Bacillus psychrosaccharolyticus; additional function of HSP33 on resistance to solvent stress. Biochemical and biophysical research communications. 2007 Jul 6;358(3):743-50.

72. Okochi M, Kanie K, Kurimoto M, Yohda M, Honda H. Overexpression of prefoldin from the hyperthermophilic archaeum Pyrococcus horikoshii OT3 endowed Escherichia coli with organic solvent tolerance. Applied microbiology and biotechnology. 2008 Jun 1;79(3):443-9.

73. Knoshaug EP, Zhang M. Butanol tolerance in a selection of microorganisms. Applied biochemistry and biotechnology. 2009 May 1;153(1-3):13-20.

74. Zingaro KA, Papoutsakis ET. Toward a semisynthetic stress response system to engineer microbial solvent tolerance. Mbio. 2012 Nov 1;3(5):e00308-12.

75.Zingaro KA, Papoutsakis ET. GroESL overexpression imparts Escherichia coli tolerance to i-, n-, and 2-butanol, 1, 2, 4-butanetriol and ethanol with complex and unpredictable patterns. Metabolic engineering. 2013 Jan 31;15:196-205.

76. Aono R, Tsukagoshi N, Yamamoto M. Involvement of outer membrane protein TolC, a possible member 
of the mar-sox regulon, in maintenance and improvement of organic solvent tolerance of Escherichia coli K-12. Journal of bacteriology. 1998 Feb 15;180(4):938-44.

77. Ni Y, Song L, Qian X, Sun Z. Proteomic analysis of Pseudomonas putida reveals an organic solvent tolerance-related gene mmsB. PloS one. 2013 Feb 11;8(2):e55858.

78. Qian X, Song L, Ni Y. Enhanced organic solvent tolerance of Escherichia coli by 3-hydroxyacid dehydrogenase family genes. Applied biochemistry and biotechnology. 2014 Mar 1;172(6):3106-15.

79. Shen CR, Liao JC. Metabolic engineering of Escherichia coli for 1-butanol and 1-propanol production via the keto-acid pathways. Metabolic engineering. 2008 Nov 30;10(6):312-20.

80. Steen EJ, Chan R, Prasad N, Myers S, Petzold CJ, Redding A, Ouellet M, Keasling JD. Metabolic engineering of Saccharomyces cerevisiae for the production of $\mathrm{n}$-butanol. Microbial cell factories. 2008 Dec 3;7(1):1.

81. Dusséaux S, Croux C, Soucaille P, Meynial-Salles I. Metabolic engineering of Clostridium acetobutylicum ATCC 824 for the high-yield production of a biofuel composed of an isopropanol/butanol/ethanol mixture. Metabolic engineering. 2013 Jul 31;18:1-8.

82. Sillers R, Chow A, Tracy B, Papoutsakis ET. Metabolic engineering of the non-sporulating, nonsolventogenic Clostridium acetobutylicum strain M5 to produce butanol without acetone demonstrate the robustness of the acid-formation pathways and the importance of the electron balance. Metabolic engineering. 2008 Nov 30;10(6):321-32.

83. Chen L, Shang G, Yuan W, Wu Y, Bai F. [Screening of Clostridium strains through ribosome engineering for improved butanol production]. Sheng wu gong cheng xue $b a o=$ Chinese journal of biotechnology. 2012 Sep;28(9):1048-58.

84. Cai X, Bennett GN. Improving the Clostridium acetobutylicum butanol fermentation by engineering the strain for co-production of riboflavin. Journal of industrial microbiology \& biotechnology. 2011 Aug 1;38(8):1013-25.

85. Lee J, Jang YS, Choi SJ, Im JA, Song H, Cho JH, Papoutsakis ET, Bennett GN, Lee SY. Metabolic engineering of Clostridium acetobutylicum ATCC 824 for isopropanol-butanol-ethanol fermentation. Applied and environmental microbiology. 2012 Mar 1;78(5):1416-23.

86. Bankar SB, Jurgens G, Survase SA, Ojamo H, Granström T. Genetic engineering of Clostridium acetobutylicum to enhance isopropanol-butanolethanol production with an integrated DNAtechnology approach. Renewable Energy. 2015 Nov 30;83:1076-83.

87. Yu M, Zhang Y, Tang IC, Yang ST. Metabolic engineering of Clostridium tyrobutyricum for n- butanol production. Metabolic engineering. $2011 \mathrm{Jul}$ 31;13(4):373-82.

88. Smith A, Medisetty M, Huang WH, Priola J, Ren D. Engineering Escherichia Coli for Improved Ethanol and Butanol Tolerance for Biofuel Production. InThe 2008 Annual Meeting 2008.

89. Jeong H, Han J. Enhancing the 1-butanol tolerance in Escherichia coli through repetitive proton beam irradiation.Journal of Korean Physical Society. 2010.

90. Winkler J, Rehmann M, Kao KC. Novel Escherichia coli hybrids with enhanced butanol tolerance. Biotechnology letters. 2010 Jul 1;32(7):915-20.

91. Reyes LH, Almario MP, Kao KC. Genomic library screens for genes involved in n-butanol tolerance in Escherichia coli. PloS one. 2011 Mar 8;6(3):e17678.

92. Liyanage H, Young M, Kashket ER. Butanol tolerance of Clostridium beijerinckii NCIMB 8052 associated with down-regulation of gldA by antisense RNA. Journal of molecular microbiology and biotechnology. 2000 Jan 1;2(1):87-93.

93. Tomas CA, Beamish J, Papoutsakis ET. Transcriptional analysis of butanol stress and tolerance in Clostridium acetobutylicum. Journal of bacteriology. 2004 Apr 1;186(7):2006-18.

94. Bao G, Dong H, Zhu Y, Mao S, Zhang T, Zhang Y, Chen Z, Li Y. Comparative genomic and proteomic analyses of Clostridium acetobutylicum Rh8 and its parent strain DSM 1731 revealed new understandings on butanol tolerance. Biochemical and biophysical research communications. 2014 Aug 8;450(4):1612-8.

95. Liu XB, Gu QY, Yu XB, Luo W. Enhancement of butanol tolerance and butanol yield in Clostridium acetobutylicum mutant NT642 obtained by nitrogen ion beam implantation. Journal of Microbiology. 2012 Dec 1;50(6):1024-8.

96. Lan EI, Liao JC. Microbial synthesis of n-butanol, isobutanol, and other higher alcohols from diverse resources. Bioresource technology. 2013 May 31;135:339-49.

97. González-Ramos D, van den Broek M, van Maris AJ, Pronk JT, Daran JM. Genome-scale analyses of butanol tolerance in Saccharomyces cerevisiae reveal an essential role of protein degradation. Biotechnology for biofuels. 2013 Apr 3;6(1):1

98. Kanno M, Katayama T, Tamaki H, Mitani Y, Meng $\mathrm{XY}$, Hori $\mathrm{T}$, Narihiro $\mathrm{T}$, Morita $\mathrm{N}$, Hoshino $\mathrm{T}$, Yumoto I, Kimura N. Isolation of butanol-and isobutanol-tolerant bacteria and physiological characterization of their butanol tolerance. Applied and environmental microbiology. 2013 Nov 15;79(22):6998-7005.

99. Kaczmarzyk D, Anfelt J, Särnegrim A, Hudson EP. Overexpression of sigma factor $\mathrm{Sig} B$ improves temperature and butanol tolerance of Synechocystis sp. PCC6803. Journal of biotechnology. 2014 Aug 10;182:54-60. 
Rao, A et al.

Received: January 15,2016

Accepted: May11, 2016

Braz. Arch. Biol. Technol. v.59: e161506120, Jan/Dec 2016 